4

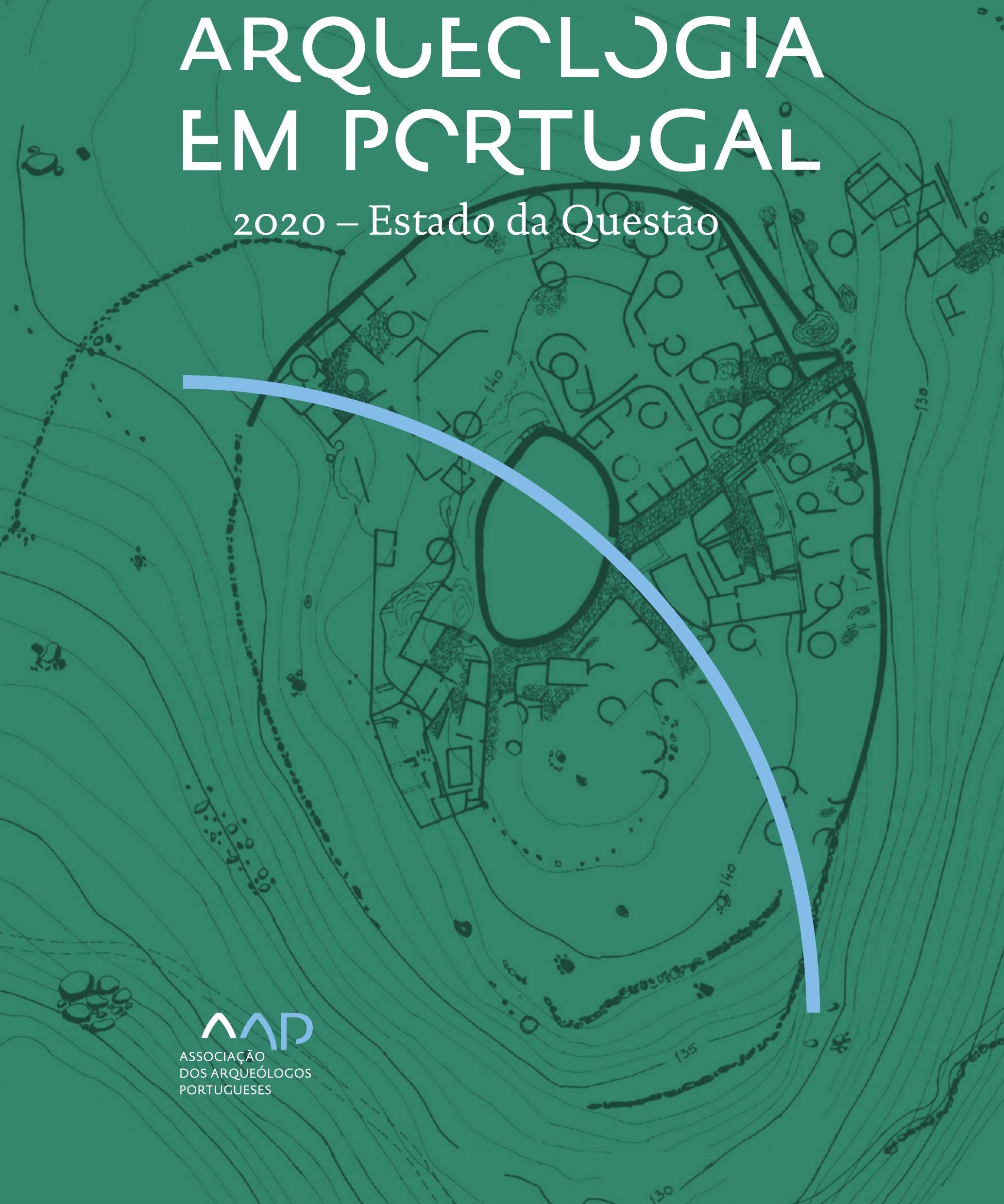


Coordenação editorial: José Morais Arnaud, César Neves e Andrea Martins Design gráfico: Flatland Design

AAP - ISBN: 978-972-9451-89-8

CITCEM - ISBN: 978-989-8970-25-1

Associação dos Arqueólogos Portugueses e CITCEM

Lisboa, 2020

O conteúdo dos artigos é da inteira responsabilidade dos autores. Sendo assim a Associação dos Arqueólogos Portugueses declina qualquer responsabilidade por eventuais equívocos ou questões de ordem ética e legal.

Desenho de capa:

Planta do castro de Monte Mozinho (Museu Municipal de Penafiel).

\section{$\hat{\wedge} \mathrm{P}$}

DOS ARQUEÓLOGOS PORTUGUESES

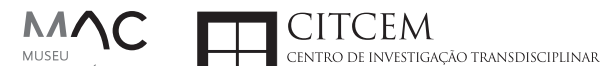
MUSEU
ARQUELLÓGICO
DO CARMO
U.PORTO

FLUP FACULDADE DE LETRAS
UNIVERSIDADE DO PORTO

Apoio

EC para a Ciência 


\section{Índice}

15 Prefácio

José Morais Arnaud

\section{Historiografia e Teoria}

17 Território, comunidade, memória e emoção: a contribuição da história da arqueologia (algumas primeiras e breves reflexões)

Ana Cristina Martins

25 Como descolonizar a arqueologia portuguesa?

Rui Gomes Coelho

41 Arqueologia e Modernidade: uma revisitação pessoal e breve de alguns aspetos da obra homónima de Julian Thomas de 2004

Vítor Oliveira Jorge

57 Dados para a História das Mulheres na Arqueologia portuguesa, dos finais do século XIX aos inícios do século XX: números, nomes e tabelas

Filipa Dimas / Mariana Diniz

73 Retractos da arqueologia portuguesa na imprensa: (in)visibilidades no feminino

Catarina Costeira / Elsa Luís

85 Arqueologia e Arqueólogos no Norte de Portugal Jacinta Bugalhão

101 Vieira Guimarães (1864-1939) e a arqueologia em Tomar: uma abordagem sobre o território e as gentes

João Amendoeira Peixoto / Ana Cristina Martins

115 Os memoráveis? A arqueologia algarvia na imprensa nacional e regional na presente centúria (2001-2019): características, visões do(s) passado(s) e a arqueologia

enquanto marca

Frederico Agosto / João Silva

129 A Evolução da Arqueologia Urbana e a Valorização Patrimonial no Barlavento Algarvio: Os casos de Portimão e Silves

Artur Mateus / Diogo Varandas / Rafael Boavida

\section{Gestão, Valorização e Salvaguarda do Património}

145 O Caderno Reivindicativo e as condições de trabalho em Arqueologia Miguel Rocha / Liliana Matias Carvalho / Regis Barbosa / Mauro Correia / Sara Simões / Jacinta Bugalhão / Sara Brito / Liliana Veríssimo Carvalho / Richard Peace / Pedro Peça / Cézer Santos

155 Os Estudos de Impacte Patrimonial como elemento para uma estratégia sustentável de minimização de impactes no âmbito de reconversões agrícolas Tiago do Pereiro

165 Salvaguarda de Património arqueológico em operações florestais: gestão e sensibilização Filipa Bragança / Gertrudes Zambujo / Sandra Lourenço / Belém Paiva / Carlos Banha / Frederico Tatá Regala / Helena Moura / Jacinta Bugalhão / João Marques / José Correia / Pedro Faria / Samuel Melro

179 Os valores do Património: uma investigação sobre os Sítios Pré-históricos de Arte Rupestre do Vale do Rio Côa e de Siega Verde José Paulo Francisco 
189 Conjugando recursos arqueológicos e naturais para potenciar as visitas ao Geoparque Litoral de Viana do Castelo (Noroeste de Portugal)

Hugo A. Sampaio / Ana M.S. Bettencourt / Susana Marinho / Ricardo Carvalhido

203 Áreas de Potencial Arqueológico na Região do Médio Tejo: Modelo Espacial Preditivo Rita Ferreira Anastácio / Ana Filipa Martins / Luiz Oosterbeek

223 Património Arqueológico e Gestão Territorial: O contributo da Arqueologia para a revisão do PDM de Avis

Ana Cristina Ribeiro

237 A coleção arqueológica do extinto Museu Municipal do Porto - Origens, Percursos e Estudos

Sónia Couto

251 Valpaços - uma nova carta arqueológica

Pedro Pereira / Maria de Fátima Casares Machado

263 Arqueologia na Cidade de Peniche

Adriano Constantino / Luís Rendeiro

273 Arqueologia Urbana: a cidade de Lagos como caso de Estudo Cátia Neto

285 Estratégias de promoção do património cultural subaquático nos Açores. O caso da ilha do Faial

José Luís Neto / José Bettencourt / Luís Borges / Pedro Parreira

297 Carta Arqueológica da Cidade Velha: Uma primeira abordagem

Jaylson Monteiro / Nireide Tavares / Sara da Veiga / Claudino Ramos / Edson Brito /

Carlos Carvalho / Francisco Moreira / Adalberto Tavares

311 Antropologia Virtual: novas metodologias para a análise morfológica e funcional Ricardo Miguel Godinho / Célia Gonçalves

\section{Didáctica da Arqueologia}

327 Como os projetos de Arqueologia podem contribuir para uma comunidade culturalmente mais consciente Alexandra Figueiredo / Claúdio Monteiro / Adolfo Silveira / Ricardo Lopes

337 Educação Patrimonial - Um cidadão esclarecido é um cidadão ativo! Ana Paula Almeida

351 A aproximação da Arqueologia à sala de aula: um caso de estudo no $3^{\circ}$ ciclo do Ensino Básico Luís Serrão Gil

363 Arqueologia 3.o - Pensar e comunicar a Arqueologia para um futuro sustentável Mónica Rolo

377 “Conversa de Arqueólogos" - Divulgar a Arqueologia em tempos de Pandemia Diogo Teixeira Dias

389 Escola Profissional de Arqueologia: desafios e oportunidades Susana Nunes / Dulcineia Pinto / Júlia Silva / Ana Mascarenhas

399 Os Museus de Arqueologia e os Jovens: a oferta educativa para o público adolescente Beatriz Correia Barata / Leonor Medeiros

411 O museu universitário como mediador entre a ciência e a sociedade: o exemplo da secção de arqueologia no Museu de História Natural e da Ciência da Universidade do Porto (MHNC-UP)

Rita Gaspar 
421 Museu de Lanifícios: Real Fábrica de Panos. Atividades no âmbito da Arqueologia Beatriz Correia Barata / Rita Salvado

427 Arqueologia Pública e o caso da localidade da Mata (Torres Novas) Cláudia Manso / Ana Rita Ferreira / Cristiana Ferreira / Vanessa Cardoso Antunes

431 Do sítio arqueológico ao museu: um percurso (também) didático Lídia Fernandes

447 Estão todos convidados para a Festa! E para dançar também... O projecto do Serviço Educativo do Museu Arqueológico do Carmo na $5^{\underline{a}}$ Edição da Festa da Arqueologia Rita Pires dos Santos

459 O “Clã de Carenque”, um projeto didático de arqueologia Eduardo Gonzalez Rocha

469 Mediação cultural: peixe que puxa carroça nas Ruínas Romanas de Troia Inês Vaz Pinto / Ana Patrícia Magalhães / Patrícia Brum / Filipa Santos

481 Didática Arqueológica, experiências do Projeto Mértola Vila Museu Maria de Fátima Palma / Clara Rodrigues / Susana Gómez / Lígia Rafael

\section{Arte Rupestre}

497 Os inventários de arte rupestre em Portugal Mila Simões de Abreu

513 O projeto FIRST-ART - conservação, documentação e gestão das primeiras manifestações de arte rupestre no Sudoeste da Península Ibérica: as grutas do Escoural e Maltravieso Sara Garcês / Hipólito Collado / José Julio García Arranz / Luiz Oosterbeek / António Carlos Silva / Pierluigi Rosina / Hugo Gomes / Anabela Borralheiro Pereira / George Nash / Esmeralda Gomes / Nelson Almeida / Carlos Carpetudo

523 Trabalhos de documentação de arte paleolítica realizados no âmbito do projeto PalæoCôa André Tomás Santos / António Fernando Barbosa / Luís Luís / Marcelo Silvestre / Thierry Aubry

537 Imagens fantasmagóricas, silhuetas elusivas: as figuras humanas na arte do Paleolítico Superior da região do Côa Mário Reis

$55^{1}$ Os motivos zoomórficos representados nas placas de tear de Vila Nova de São Pedro (Azambuja, Portugal) Andrea Martins / César Neves / José M. Arnaud / Mariana Diniz

571 Arte Rupestre do Monte de Góios (Lanhelas, Caminha). Síntese dos resultados dos trabalhos efectuados em 2007-2009 Mário Varela Gomes

599 Gravuras rupestres de barquiformes no Monte de S. Romão, Guimarães, Noroeste de Portugal Daniela Cardoso

613 Círculos segmentados gravados na Bacia do Rio Lima (Noroeste de Portugal): contributos para o seu estudo Diogo Marinho / Ana M.S. Bettencourt / Hugo Aluai Sampaio

631 Equídeos gravados no curso inferior do Rio Mouro, Monção (NW Portugal). Análise preliminar Coutinho, L.M. / Bettencourt, A.M.S / Sampaio, Hugo A.S

645 Paletas na Arte Rupestre do Noroeste de Portugal. Inventário preliminar Bruna Sousa Afonso / Ana M. S. Bettencourt / Hugo A. Sampaio 


\section{Pré-História}

661 O projeto Miño/Minho: balanço de quatro anos de trabalhos arqueológicos Sérgio Monteiro-Rodrigues / João Pedro Cunha-Ribeiro / Eduardo Méndez-Quintas / Carlos Ferreira / Pedro Xavier / José Meireles / Alberto Gomes / Manuel Santonja / Alfredo Pérez-González

677 A ocupação paleolítica da margem esquerda do Baixo Minho: a indústria lítica do sítio de Pedreiras 2 (Monção, Portugal) e a sua integração no contexto regional Carlos Ferreira / João Pedro Cunha-Ribeiro / Sérgio Monteiro-Rodrigues / Eduardo Méndez-Quintas / Pedro Xavier / José Meireles / Alberto Gomes / Manuel Santonja / Alfredo Pérez-González

693 O sítio acheulense do Plistocénico médio da Gruta da Aroeira Joan Daura / Montserrat Sanz / Filipa Rodrigues / Pedro Souto / João Zilhão

703 As sociedades neandertais no Barlavento algarvio: modelos preditivos com recurso aos SIG

Daniela Maio

715 A utilização de quartzo durante o Paleolítico Superior no território dos vales dos rios Vouga e Côa

Cristina Gameiro / Thierry Aubry / Bárbara Costa / Sérgio Gomes / Luís Luís / Carmen Manzano / André Tomás Santos

733 Uma perspetiva diacrónica da ocupação do concheiro do Cabeço da Amoreira (Muge, Portugal) a partir da tecnologia lítica Joana Belmiro / João Cascalheira / Célia Gonçalves

745 Novos dados sobre a Pré-história Antiga no concelho de Palmela. A intervenção arqueológica no sítio do Poceirão I

Michelle Teixeira Santos

757 Problemas em torno de Datas Absolutas Pré-Históricas no Norte do Alentejo Jorge de Oliveira

771 Povoamento pré-histórico nas áreas montanhosas do NO de Portugal: o Abrigo 1 de Vale de Cerdeira Pedro Xavier / José Meireles / Carlos Alves

783 Apreciação do povoamento do Neolítico Inicial na Baixa Bacia do Douro. A Lavra I (Serra da Aboboreira) como caso de estudo Maria de Jesus Sanches

797 O Processo de Neolitização na Plataforma do Mondego: os dados do Sector C do Outeiro dos Castelos de Beijós (Carregal do Sal)

João Carlos de Senna-Martinez / José Manuel Quintã Ventura / Andreia Carvalho / Cíntia Maurício

823 Novos trabalhos na Lapa da Bugalheira (Almonda, Torres Novas) Filipa Rodrigues / Pedro Souto / Artur Ferreira / Alexandre Varanda / Luís Gomes / Helena Gomes / João Zilhão

837 A pedra polida e afeiçoada do sítio do Neolítico médio da Moita do Ourives (Benavente, Portugal)

César Neves

857 Casal do Outeiro (Encarnação, Mafra): novos contributos para o conhecimento do povoamento do Neolítico final na Península de Lisboa.

Cátia Delicado / Carlos Maneira e Costa / Marta Miranda / Ana Catarina Sousa

873 Stresse infantil, morbilidade e mortalidade no sítio arqueológico do Neolítico Final/ Calcolítico ( $4^{\circ}$ e $3^{\circ}$ milénio a.C.) do Monte do Carrascal 2 (Ferreira do Alentejo, Beja) Liliana Matias de Carvalho / Sofia N. Wasterlain 
885 Come together: O Conjunto Megalítico das Motas (Monção, Viana do Castelo) e as expressões Campaniformes do Alto Minho Ana Catarina Basílio / Rui Ramos

899 Trabalhos arqueológicos no sítio Calcolítico da Pedreira do Poio Carla Magalhães / João Muralha / Mário Reis / António Batarda Fernandes

913 O sítio arqueológico de Castanheiro do Vento. Da arquitectura do sítio à arquitectura de um território João Muralha Cardoso

925 Estudo zooarqueológico das faunas do Calcolítico final de Vila Nova de São Pedro (Azambuja, Portugal): Campanhas de 2017 e 2018 Cleia Detry / Ana Catarina Francisco / Mariana Diniz / Andrea Martins / César Neves / José Morais Arnaud

943 As faunas depositadas no Museu Arqueológico do Carmo provenientes de Vila Nova de São Pedro (Azambuja): as campanhas de 1937 a 1967 Ana Catarina Francisco / Cleia Detry / César Neves / Andrea Martins / Mariana Diniz / José Morais Arnaud

959 Análise funcional de material lítico em sílex do castro de Vila Nova de S. Pedro (Azambuja, Portugal): uma primeira abordagem Rafael Lima

971 O recinto da Folha do Ouro 1 (Serpa) no contexto dos recintos de fossos calcolíticos alentejanos

António Carlos Valera / Tiago do Pereiro / Pedro Valério / António M. Monge Soares

\section{Proto-História}

987 Produção de sal marinho na Idade do Bronze do noroeste Português. Alguns dados para uma reflexão

Ana M. S. Bettencourt / Sara Luz / Nuno Oliveira / Pedro P. Simões / Maria Isabel C. Alves / Emílio Abad-Vidal

1001 A estátua-menir do Pedrão ou de São Bartolomeu do Mar (Esposende, noroeste de Portugal) no contexto arqueológico da fachada costeira de entre os rios Neiva e Cávado Ana M. S. Bettencourt / Manuel Santos-Estévez / Pedro Pimenta Simões / Luís Gonçalves

1015 O Castro do Muro (Vandoma/Baltar, Paredes) - notas para uma biografia de ocupação da Idade do Bronze à Idade Média

Maria Antónia D. Silva / Ana M. S. Bettencourt / António Manuel S. P. Silva / Natália Félix

1031 Do Bronze Final à Idade Média - continuidades e hiatos na ocupação de Povoados em Oliveira de Azeméis João Tiago Tavares / Adriaan de Man

1041 As faunas do final da Idade do Bronze no Sul de Portugal: leituras desde o Outeiro do Circo (Beja)

Nelson J. Almeida / Íris Dias / Cleia Detry / Eduardo Porfírio / Miguel Serra

1055 A Espada do Monte das Oliveiras (Serpa) - uma arma do Bronze Pleno do Sudoeste Rui M. G. Monge Soares / Pedro Valério / Mariana Nabais / António M. Monge Soares

1065 São Julião da Branca (Albergaria-a-Velha) - Investigação e valorização de um povoado do Bronze Final

António Manuel S. P. Silva / Paulo A. P. Lemos / Sara Almeida e Silva / Edite Martins de Sá

1083 Do castro de S. João ao Mosteiro de Santa Clara: notícia de uma intervenção arqueológica, em Vila do Conde Rui Pinheiro 
1095 O castro de Ovil (Espinho), um quarto de século de investigação - resultados e questões em aberto

Jorge Fernando Salvador / António Manuel S. P. Silva

1111 O Castro de Salreu (Estarreja), um povoado proto-histórico no litoral do Entre Douro e Vouga

Sara Almeida e Silva / António Manuel S. P. Silva / Paulo A. P. Lemos / Edite Martins de Sá

1127 Castro de Nossa Senhora das Necessidades (Sernancelhe): uma primeira análise artefactual Telma Susana O. Ribeiro

${ }_{1141}$ A cividade de Bagunte. O estado atual da investigação Pedro Brochado de Almeida

1153 Zoomorfos na cerâmica da Idade do Ferro no NW Peninsular: inventário, cronologias e significado Nuno Oliveira / Cristina Seoane

1163 Vasos gregos em Portugal: diferentes maneiras de contar a história do intercâmbio cultural na Idade do Ferro

Daniela Ferreira

1175 Os exotica da necrópole da Idade do Ferro do Olival do Senhor dos Mártires (Alcácer do Sal) no seu contexto regional

Francisco B. Gomes

\section{Antiguidade Clássica e Tardia}

1191 O uso de madeira como combustível no sítio da Quinta de Crestelos (Baixo Sabor): da Idade do Ferro à Romanização Filipe Vaz / João Tereso / Sérgio Simões Pereira / José Sastre / Javier Larrazabal Galarza / Susana Cosme / José António Pereira / Israel Espi

1207 Cultivos de Época Romana no Baixo Sabor: continuidade em tempos de mudança? João Pedro Tereso / Sérgio Simões Pereira / Filipe Santos / Luís Seabra / Filipe Vaz

1221 A casa romana na Hispânia: aplicação dos modelos itálicos nas províncias ibéricas Fernanda Magalhães / Diego Machado / Manuela Martins

1235 As pinturas murais romanas da Rua General Sousa Machado, n. ${ }^{5}$ 1, Chaves José Carvalho

1243 Trás do Castelo (Vale de Mir, Pegarinhos, Alijó) - Uma exploração agrícola romana do Douro

Tony Silvino / Pedro Pereira

1255 A sequência de ocupação no quadrante sudeste de Bracara Augusta: as transformações de uma unidade doméstica Lara Fernandes / Manuela Martins

1263 Os Mosaicos com decoração geométrica e geométrico-vegetalista dos sítios arqueológicos da área do Conuentus Bracaraugustanus. Novas abordagens quanto à conservação, restauro, decoração e datação Maria de Fátima Abraços / Licínia Wrench

1277 “Casa Romana” do Castro de São Domingos (Cristelos, Lousada): Escavação, Estudo e Musealização Paulo André de P. Lemos

1291 A arqueobotânica no Castro de Guifões (Matosinhos, Noroeste de Portugal): O primeiro estudo carpológico

Luís Seabra / Andreia Arezes / Catarina Magalhães / José Varela / João Pedro Tereso 
1305 Um Horreum Augustano na Foz do Douro (Monte do Castelo de Gaia, Vila Nova de Gaia) Rui Ramos

1311 Ponderais romanos na Lusitânia: padrões, formas, materiais e contextos de utilização Diego Barrios Rodríguez

1323 Um almofariz centro-itálico na foz do Mondego

Marco Penajoia

1335 Estruturas romanas de Carnide - Lisboa Luísa Batalha / Mário Monteiro / Guilherme Cardoso

1347 O contexto funerário do sector da "necrópole NO" da Rua das Portas de S. Antão (Lisboa): o espaço, os artefactos, os indivíduos e a sua interconectividade na interpretação do passado Sílvia Loja, José Carlos Quaresma, Nelson Cabaço, Marina Lourenço, Sílvia Casimiro, Rodrigo Banha da Silva, Francisca Alves-Cardoso

${ }_{1361}$ Povoamento em época Romana na Amadora - resultados de um projeto pluridisciplinar Gisela Encarnação / Vanessa Dias

1371 A Arquitectura Residencial em Mirobriga (Santiago do Cacém): contributo a partir de um estudo de caso Filipe Sousa / Catarina Felício

${ }_{1385}$ O fim do ciclo. Saneamento e gestão de resíduos nos edifícios termais de Mirobriga (Santiago do Cacém)

Catarina Felício / Filipe Sousa

1399 Balsa, Topografia e Urbanismo de uma Cidade Portuária Vítor Silva Dias / João Pedro Bernardes / Celso Candeias / Cristina Tété Garcia

1413 No Largo das Mouras Velhas em Faro (2017): novas evidências da necrópole norte de Ossonoba e da sua ocupação medieval Ricardo Costeira da Silva / Paulo Botelho / Fernando Santos / Liliana Nunes

1429 Instrumentos de pesca recuperados numa fábrica de salga em Ossonoba (Faro) Inês Rasteiro / Ricardo Costeira da Silva / Paulo Botelho

1439 A Necrópole Romana do Eirô, Duas Igrejas (Penafiel): intervenção arqueológica de 2016 Laura Sousa / Teresa Soeiro

1457 Ritual, descarte ou afetividade? A presença de Canis lupus familiaris na Necrópole Noroeste de Olisipo (Lisboa)

Beatriz Calapez Santos / Sofia Simões Pereira / Rodrigo Banha da Silva / Sílvia Casimiro / Cleia Detry / Francisca Alves Cardoso

1467 Dinâmicas económicas em Bracara na Antiguidade Tardia Diego Machado / Manuela Martins / Fernanda Magalhães / Natália Botica

1479 Cerâmicas e Vidros da Antiguidade Tardia do Edifício sob a Igreja do Bom Jesus (Vila Nova de Gaia) Joaquim Filipe Ramos

1493 Novos contributos para a topografia histórica de Mértola no período romano e na Antiguidade Tardia Virgílio Lopes

\section{8. Época Medieval}

1511 Cerâmicas islâmicas no Garb setentrional "português": algumas evidências e incógnitas Constança dos Santos / Helena Catarino / Susana Gómez / Maria José Gonçalves / Isabel Inácio / Gonçalo Lopes / Jacinta Bugalhão / Sandra Cavaco / Jaquelina Covaneiro / Isabel Cristina Fernandes / Ana Sofia Gomes 
1525 Contributo para o conhecimento da cosmética islâmica, em Silves, durante a Idade Média Rosa Varela Gomes

1537 Yábura e o seu território - uma análise histórico-arqueológica de Évora entre os séculos VIII-XII José Rui Santos

1547 A encosta sul do Castelo de Palmela - resultados preliminares da escavação arqueológica Luís Filipe Pereira / Michelle Teixeira Santos

1559 A igreja de São Lourenço (Mouraria, Lisboa): um conjunto de silos e de cerâmica medieval islâmica

Andreia Filipa Moreira Rodrigues

1571 O registo material de movimentações populacionais no Médio Tejo, durante os séculos XII-XIII. Dois casos de "sunken featured buildings", nos concelhos de Cartaxo e Torres Novas Marco Liberato / Helena Santos / Nuno Santos

1585 O nordeste transmontano nos alvores da Idade média. Notas para reflexão Ana Maria da Costa Oliveira

1601 Sepulturas escavadas na rocha do Norte de Portugal e do Vale do Douro: primeiros resultados do Projecto SER-NPVD

Mário Jorge Barroca / César Guedes / Andreia Arezes / Ana Maria Oliveira

1619 "Portucalem Castrum Novum" entre o Mediterrâneo e o Atlântico: o estudo dos materiais cerâmicos alto-medievais do arqueossítio da rua de D. Hugo, nํ. 5 (Porto) João Luís Veloso

1627 A Alta Idade Média na fronteira de Lafões: notas preliminares sobre a Arqueologia no Concelho de Vouzela

Manuel Luís Real / Catarina Tente

1641 Um conjunto cerâmico medieval fora de portas: um breve testemunho aveirense Susana Temudo

${ }_{1651}$ Os Lóios do Porto: uma perspetiva integrada no panorama funerário da Baixa Idade Média à Época Moderna em meios urbanos em Portugal

Ana Lema Seabra

1659 O Caminho Português Interior de Santiago como eixo viário na Idade Média Pedro Azevedo

1665 Morfologia Urbana: Um exercício em torno do Castelo de Ourém André Donas-Botto / Jaqueline Pereira

1677 Intervenção arqueológica na Rua Marquês de Pombal/Largo do Espírito Santo (Bucelas, Loures)

Florbela Estêvão / Nathalie Antunes-Ferreira / Dário Ramos Neves / Inês Lisboa

1691 O Cemitério Medieval do Poço do Borratém e a espacialidade funerária na cidade de Lisboa Inês Belém / Vanessa Filipe / Vasco Noronha Vieira / Sónia Ferro / Rodrigo Banha da Silva

1705 Um Espaço Funerário Conventual do séc. XV em Lisboa: o caso do Convento de São Domingos da Cidade Sérgio Pedroso / Sílvia Casimiro / Rodrigo Banha da Silva / Francisca Alves Cardoso

\section{9. Época Moderna e Contemporânea}

1721 Arqueologia Moderna em Portugal: algumas reflexões críticas em torno da quantificação de conjuntos cerâmicos e suas inferências históricas e antropológicas Rodrigo Banha da Silva / André Bargão / Sara da Cruz Ferreira

1733 Faianças de dois contextos entre os finais do século XVI e XVIII do Palácio dos Condes de Penafiel, Lisboa

Martim Lopes / Tomás Mesquita 
1747 Um perfil de consumo do século XVIII na foz do Tejo: O caso do Mercado da Ribeira, Lisboa Sara da Cruz Ferreira / Rodrigo Banha da Silva / André Bargão

1761 Os Cachimbos dos Séculos XVII e XVIII do Palácio Mesquitela e Convento dos Inglesinhos (Lisboa)

Inês Simão / Marina Pinto / João Pimenta / Sara da Cruz Ferreira / André Bargão / Rodrigo Banha da Silva

1775 "Tomar os fumos da erua que chamão em Portugal erua sancta». Estudo de Cachimbos provenientes da Rua do Terreiro do Trigo, Lisboa

Miguel Martins de Sousa / José Pedro Henriques / Vanessa Galiza Filipe

1787 Cachimbos de Barro Caulínitico da Sé da Cidade Velha (República de Cabo Verde)

Rodrigo Banha da Silva / João Pimenta / Clementino Amaro

1801 Algumas considerações sobre espólio não cerâmico recuperado no Largo de Jesus (Lisboa) Carlos Boavida

1815 Adereços de vidro, dos séculos XVI-XVIII, procedentes do antigo Convento de Santana de Lisboa (anéis, braceletes e contas)

Joana Gonçalves / Rosa Varela Gomes / Mário Varela Gomes

1837 Da ostentação, luxo e poder à simplicidade do uso quotidiano: arqueologia e simbologia de joias e adornos da Idade Moderna Portuguesa Jéssica Iglésias

1849 Os amuletos em Portugal - dos objetos às superstições: o coral vermelho Alexandra Vieira

1865 Cerâmicas de Vila Franca de Xira nos séculos XV e XVI Eva Pires

1879 «Não passa por teu o que me pertence». Marcas de individualização associadas a faianças do Convento de Nossa Senhora de Aracoeli, Alcácer do Sal Catarina Parreira / Íris Fragoso / Miguel Martins de Sousa

1891 Cerâmica de Leiria: alguns focos de produção

Jaqueline Pereira / André Donas-Botto

1901 Os Fornos na Rua da Biquinha, em Óbidos Hugo Silva / Filipe Oliveira

1909 A casa de Pêro Fernandes, contador dos contos de D. Manuel I: o sítio arqueológico da Silha do Alferes, Seixal (século XVI) Mariana Nunes Ferreira

1921 O Alto da Vigia (Sintra) e a vigilância e defesa da costa Alexandre Gonçalves / Sandra Santos

1937 O contexto da torre sineira da Igreja de Santa Maria de Loures Paulo Calaveira / Martim Lopes

1949 A Necrópole do Hospital Militar do Castelo de São Jorge e as práticas funerárias na Lisboa de Época Moderna Susana Henriques / Liliana Matias de Carvalho / Ana Amarante / Sofia N. Wasterlain

1963 SAND - Sarilhos Grandes Entre dois Mundos: o adro da Igreja e a Paleobiologia dos ossos humanos recuperados

Paula Alves Pereira / Roger Lee Jesus / Bruno M. Magalhães

1975 Expansão urbana da vila de Cascais no século XVII e XVIII: a intervenção arqueológica na Rua da Vitória no 15 a 17

Tiago Pereira / Vanessa Filipe

1987 Novos dados para o conhecimento do Urbanismo de Faro em época Moderna Ana Rosa 
1995 Um exemplo de Arqueologia Urbana em Alcoutim: o Antigo Edifício dos CTT Marco Fernandes / Marta Dias / Alexandra Gradim / Virgílio Lopes / Susana Gómez Martínez

2007 Palácio dos Ferrazes (Rua das Flores/Rua da Vitória, Porto): a cocheira de Domingos Oliveira Maia

Francisco Raimundo

2021 As muitas vidas de um edifício urbano: História, Arqueologia e Antropologia no antigo Recreatório Paroquial de Penafiel Helena Bernardo / Jorge Sampaio / Marta Borges

2035 O convento de Nossa Senhora da Esperança de Ponta Delgada: o contributo da arqueologia para o conhecimento de um monumento identitário João Gonçalves Araújo / N’Zinga Oliveira

2047 Arqueologia na ilha do Corvo... em busca da capela de Nossa Senhora do Rosário Tânia Manuel Casimiro / José Luís Neto / Luís Borges / Pedro Parreira

2059 Perdidos à vista da Costa. Trabalhos arqueológicos subaquáticos na Barra do Tejo Jorge Freire / José Bettencourt / Augusto Salgado

2071 Arqueologia marítima em Cabo Verde: enquadramento e primeiros resultados do projecto CONCHA

José Bettencourt / Adilson Dias / Carlos Lima / Christelle Chouzenoux / Cristóvão Fonseca / Dúnia Pereira / Gonçalo Lopes / Inês Coelho / Jaylson Monteiro / José Lima / Maria Eugénia Alves / Patrícia Carvalho / Tiago Silva

2085 Trabalhos arqueológicos na Cidade Velha (Ribeira Grande de Santiago, Cabo Verde): reflexões sobre um projecto de investigação e divulgação patrimonial André Teixeira / Jaylson Monteiro / Mariana Mateus / Nireide Tavares / Cristovão Fonseca / Gonçalo C. Lopes / Joana Bento Torres / Dúnia Pereira / André Bargão / Aurélie Mayer / Bruno Zélie / Carlos Lima / Christelle Chouzenoux / Inês Henriques / Inês Pinto Coelho / José Lima / Patrícia Carvalho / Tiago Silva

2103 A antiga fortificação de Quelba / Khor Kalba (E.A.U.). Resultados de quatro campanhas de escavações, problemáticas e perspectivas futuras Rui Carita / Rosa Varela Gomes / Mário Varela Gomes / Kamyar Kamyad

2123 Colónias para homens novos: arqueologia da colonização agrária fascista no noroeste ibérico Xurxo Ayán Vila / José Mạ . Señorán Martín 


\title{
OS MEMORÁVEIS? A ARQUEOLOGIA ALGARVIA NA IMPRENSA NACIONAL E REGIONAL NA PRESENTE CENTÚRIA (2001-2019): CARACTERÍSTICAS, VISÕES DO(S) PASSADO(S) E A ARQUEOLOGIA ENQUANTO MARCA
}

Frederico Agosto ${ }^{1}$, João Silva ${ }^{2}$

\begin{abstract}
RESUMO
O presente artigo ocupar-se-á da forma como os jornais - enquanto veículo de informação privilegiada com o grande público - apresentam o passado, a arqueologia e o arqueólogo. Para tal, proceder-se-á dialecticamente a um estudo comparativo entre a imprensa nacional e a imprensa regional, de forma a abarcar as diferentes realidades editoriais existentes e evidenciar os mecanismos de ambas aquando da escolha do que publicar. Por fim, e respeitando o questionário de base, far-se-á uma reflexão sobre os estereótipos relacionados com a arqueologia e a sua praxis, juntamente com a visão de passado que vinculam.

Palavras-chave: Imprensa Nacional, Imprensa Regional, Arqueologia Algarvia, Arqueologia Pública, Comodificação.
\end{abstract}

ABSTRACT

This article will deal with how newspapers - seen here as a main vehicle of information with the general public - present the past, archaeology and the archaeologist. To this end, a comparative study will dialectically be carried out between national and the regional presses, in order to encompass the different type of presses at play but as well to discriminate between the different mechanisms of both when it comes to choosing what to publish. Finally, a synthesis/concluding chapter will be dedicated to reflections on the existing stereotypes related to archaeology per se, its practice, and a critique of how the past is conveyed in the press.

Keywords: National Press, Regional Press, Algarvian Archaeology, Public Archaeology, Commodification.

«De que vitória falas, disse eu então

da que faz um escravo do teu irmão?

ou duma outra que rebenta

como um rio de fúria no peito feito tormenta

quando não há nada a perder no que se tenta?»

José Mário Branco

- Cantiga da velha mãe e dos seus dois filhos

À perenidade da sua memória

\section{INTRODUÇÃO}

A crer nos postulados construtivistas, com que as linhas do presente artigo se tecem, o conhecimento constrói-se com base nas convenções científicas e, forçosamente, com base na agnição que se possua sobre uma determinada realidade. Posto isto, e tendo em conta que os media são a principal via de acesso por parte do grande público às realidades arqueológicas, são eles que delimitam à partida as bases do que pode ser cognoscível. É o seu papel metonímico,

1. Mestrando em Arqueologia na Faculdade de Letras da Universidade de Lisboa; fosagosto@gmail.com

2. Mestrando em Arqueologia na Faculdade de Letras da Universidade de Lisboa; jodavid.ms@gmail.com 
à semelhança do já elegantemente argumentado por Shanks e Tilley (1988, p. 13) para o caso dos museus, que os torna de suma importância: as realidades que se escolhem são as únicas tornadas passíveis de ser percepcionadas e, assim, as únicas existentes - qual ilusão transcendental Kantiana (Luhmann, 2000, p. 4; vide Ribeiro, 2001, p. 82).

Tem este artigo o objectivo de compreender qual o espaço que a arqueologia portuguesa, utilizando a arqueologia algarvia como metonímia - realidade bem circunscrita geograficamente e numa zona economicamente rica e mormente assente no turismo - se perfila na imprensa nacional e regional na presente centúria, juntamente com os estereótipos relacionados com a arqueologia, a sua prática e a visão do passado vinculada por estas. Procurar-se-á também compreender quais são os conteúdos expostos ao grande público juntamente com as razões que o justificam em ambas as imprensas. Conforme crê um dos signatários (FA), a impossibilidade de se arribar a um ponto definitivo, total e final no processo de criação de conhecimento implica forçosamente que todas as "reflexões finais» aqui ensaiadas sejam sim, em verdade, mais a síntese (na sua acepção dialéctica) entre os vários elementos que servem de base para reflexões futuras do que uma qualquer conclusão que se procure definitiva.

É de matizar que a análise terá um forte pendor externalista. Não se descurará por completo, porém, algum internalismo, devido às razões já expressas por O. Moro Abadía (2009, p. 21).

\section{METODOLOGIA}

Devido à natureza dissímil da imprensa nacional e regional (vide Correia, 1998, p. 5 para uma listagem de vários elementos que diferenciam a regional), os apartados que se seguem desenvolvem-se sob o signo dialéctico, estabelecendo-se e definindo-se os elementos em confronto para, posteriormente, se dissertar sobre a síntese produzida, coadjuvada da devida interpretação.

De forma a perscrutar o objecto de análise em apreço, tomou-se como base para a imprensa nacional os seguintes jornais: Público, Expresso, Sol, Diário de Notícias, Jornal de Notícias, Observador e Correio da Manhã. O carácter fragmentário da imprensa regional, que pode só se focar a uma escala concelhia, motivou a adopção do grande jornal regional do sul português e do Algarve em particular: o Sul Informação.
O ciberespaço, segundo o ensaio sobre teoria dos media protagonizado por Wolfgang Ernst (2013, p. 138), corresponde ao momento de democratização do arquivo, pelo desmantelamento das hierarquias do espaço, chegando a um público mais generalizado e, assim, configurando-se como um melhor veículo para o estudo do objecto de análise proposto e como um melhor meio para poder responder ao questionário prévio. Destarte, a pesquisa baseou-se nas respectivas plataformas digitais dos jornais sobre notícias relacionadas com a arqueologia do Algarve.

A análise incidirá sobre cinco prismas em concreto. i) A modalidade consiste em indicar se a notícia se endereça directamente à arqueologia, ou se esta é somente trazida à colação numa outra discussão (indirecta). Permite avaliar o peso que é dado à arqueologia na discussão de grandes temáticas que sejam transversais e de manifesta relevância nos dias actuais (e.g. como se lida com o património relacionado com a escravatura).ii) A data de publicação das notícias poderá permitir entrever se existe não só alguma concentração editorial como atestar uma putativa sazonalidade nesta. Está intimamente ligada, por isso, tanto com as variáveis da modalidade como com a da natureza dos trabalhos. iii) Porventura das questões mais importantes a que se quer contribuir neste artigo está relacionada sobre a escolha dos períodos cronológicos que perfilam nos jornais nacionais e regionais. Se os jornais são poderosos dispositivos metonímicos, a exclusão de certas temporalidades pode proscrever ao oblívio certas cronologias. Perceber a razão desta exclusão é, assim, de assaz importância. iv) Através das lentes da geografia, sistematizando a espacialidade das notícias, poder-se-á compreender se existe alguma relação entre o maior poderio económico de um concelho em concreto com uma maior (ou menor) representação nas várias imprensas. v) Por fim, importa conhecer a natureza dos trabalhos arqueológicos e o seu respectivo enquadramento legal. Assim, um discurso sobre os actores, sejam eles de instituições públicas (e.g. universidades) ou oriundos da iniciativa privada (i.e. empresas), pode ser tecido.

Por fim, os dados aqui empregues foram recolhidos numa perspectiva fenomenológica, ou seja, procedendo ao trabalho mecânico de transpor para a base de dados a informação que somente constava na notícia, não se tendo "digerido a realidade» (Lyotard, 1992, p. 7) nem acrescentado informações ou cruzando com outras notícias. 


\section{RESULTADOS}

\subsection{Modalidades}

No que é atinente às modalidades, é possível concluir que na imprensa nacional a arqueologia é quase só exclusivamente mobilizada para a sua discussão directa (93,8\%) (Tabela 1).

O panorama inverte-se na imprensa regional, onde a arqueologia apresenta-se somente $68,8 \%$ de forma directa e 31,2\% indirectamente (Tabela 2).

A evidente clivagem entre as duas imprensas poderá, em parte, encontrar justificação na própria índole dos jornais: se uma tem um engajamento mais declarado com a população local, com a qual tem uma relação muito mais forte (e.g. vide Correia, 1998, p. 5; Ghizzoni, 2013, p. 136), a outra tem na obtenção de lucro uma das suas silabas tónicas (e.g. vide Pereira, 2004, p. 9; Ribeiro, 2001, p. 81). Embora não se recuse por completo que as redacções dos vários jornais nacionais não possam ter nos seus princípios um salutar espírito de missão, é inegável, até pela sua própria natureza, que uma das funções dos jornais regionais é informar em maior detalhe as populações locais sobre a sua região. Este elemento está também intimamente ligado com a sua relação com as elites locais e possíveis relações clientelares (Correia, 1998, p. 5; Pascoal, 2008, p. 11). Outra das diferenças a ter em consideração cinge-se com a parca experiência dos jornalistas da imprensa regional, os quais, possuindo "baixos níveis de capital escolar» (Pascoal, 2008, p. 6), acabam por dar azo a uma manifesta disparidade em toda a chaîne opératoire da elaboração da notícia (vide Pascoal, 2008, p. 10). A diferença na formação é, deste modo, incontornável. Ainda assim, não se nota nos jornais nacionais uma preocupação tão manifesta em mobilizar a arqueologia (e seguramente a algarvia) para a reflexão colectiva de problemáticas na ordem do dia.

Muito antes pelo contrário, é de salientar que quando esta aparece indirectamente na imprensa nacional, o que é muito raro $(6,3 \%)$, esta vem comodificada, reduzindo-a a simples produto económico: não parece haver espaço para a discussão do património arqueológico em outras grandes discussões (no sentido anglo-saxónico da expressão) enquanto um potencial educativo e de sensibilização para todos que no Algarve estudam, trabalham ou se veraneiem. Tal parece contrastar com algumas notícias evidenciadas nos jornais regionais que ligam a arqueologia, com os seus respectivos contextos, a uma declarada preocupação de arqueologia pública. A arqueologia é assim posta ao serviço de conteúdos que procuram a pedagogia, não se limitando a uma simples exposição descritiva contextual. Esta tendência é mais frequente na imprensa regional do que na imprensa nacional.

\subsection{As datas de publicação}

Os meses de maior incidências jornalística sobre a arqueologia do Algarve concentram-se, claramente, durantes os meses estivais e sobre o que imediatamente os antecede (Maio) (Tabela 3). Os demais, isoladamente, são quase epifenómenos.

Estando em relativo contraste com a imprensa nacional, denota-se que os meses de menor actividade jornalística sobre a arqueologia resumem-se ao período entre Outubro e Fevereiro - abarcando parte do Outono e o Inverno (Tabela 4).

Sem grandes surpresas, os meses mais intensos nesta matéria são os relativos ao Verão. Tal se justifica por serem os meses que, em primeiro lugar, proporcionam as condições climatéricas ideais à realização de trabalhos arqueológicos de campo e, num segundo plano, por se configurarem como os meses de interrupção lectiva, permitindo o deslocamento das equipas de directores e voluntários ao campo.

Esta proposta é acalentada e confirmada porquanto a maioria dos trabalhos arqueológicos desenvolvidos em plagas algarvias têm a indelével marca d'água das universidades e dos trabalhos de investigação (50\% em ambas as imprensas - vide apartado 3.5.).

Os outros meses, que se destacam pela negativa, são ocupados por notícias referentes a alguns trabalhos de Tipo C e B.

A maior duração no tempo das notícias relacionadas com a arqueologia por parte dos jornais regionais justifica-se por serem entidades com um olhar mais atento ao local e ao que nele se passa, contrastando, evidentemente, com a impressa nacional.

\subsection{Concelho}

Somente os concelhos de Loulé (20\%), Tavira (16,3\%) e Vila Real de Santo António (15\%) se apresentam expressivamente (Tabela 5). Os restantes não detêm especial relevância que mereça menções adicionais. Demarcando-se do evidenciado nos jornais nacionais, o olhar atento dos aparatos jornalísticos $d a$ região, pela região e para a região resultou numa multiplicidade de concelhos a poderem ser considerados estatisticamente significativos (Tabela 6). 
Loulé (19,8\%), Portimão (15,2\%), Faro (10,3\%), Silves $(13,3 \%)$, Vila do Bispo (11,4\%) e, em menor grau, Tavira (7,6\%) são os concelhos em destaque.

Embora entidades concelhias como Loulé, Tavira e Vila Real de Santo António tenham uma maior exposição mediática na imprensa nacional, o que se materializa no supra exposto, deve ser mencionado que a quase totalidade deles é relativa a um pequeno conjunto de sítios/acontecimentos. Tavira, com a cidade romana de Balsa e a exposição do Museu Nacional de Arqueologia da arqueologia do concelho; Loulé com a recente exposição, também no Museu Nacional de Arqueologia e também sobre o património arqueológico do seu território; e Vila Real de Santo António que, com as escavações em Cacela Velha, encerram a quase totalidade de notícias sobre os respectivos concelhos.

O papel recentemente desempenhado pela Câmara Municipal de Loulé enquanto promotora da actividade arqueológica, financiando trabalhos dentro do concelho e apoiando colóquios sobre trabalhos realizados nas suas fronteiras, como o realizado no dia 22 de Novembro de 2019 sobre os trinta anos da edição da tese de doutoramento de Victor Gonçalves - «Megalitismo e Metalurgia no Alto Algarve Oriente: uma aproximação integrada» (1989), em muito contribuem para um maior enlevo até a nível nacional deste concelho. Resulta natural que este se perfile como o mais bem representado nas várias redacções.

Salienta-se a quase ausência de Portimão nos jornais nacionais $(1,3 \%)$, contrastando com a sua presença mais expressiva na realidade regional $(15,2 \%)$. O móbil de tal situação, por estranho que possa parecer à primeira vista, queda-se justificada por uma só razão: são em boa parte relativas quer ao povoado de Alcalar como às suas necrópoles do $3^{\circ}$ milénio a.n.e. Como já referido, a imprensa regional tem uma maior relação com a população local, funcionando a nacional mais como um empresa privada que, através da notícia e da produção de mais-valia, visa o lucro. Destarte, a escolha do que noticiar coaduna-se intimamente com a escolha de qual o material mais passível de ser comodificado. Mesmo que se aborde esta questão num outro apartado com mais detalhe (vide apartado 3.4.), relegando-se para lá um maior detalhe argumentativo, é seguro dizer que a pré-história é muito menos vendável que um outro período histórico mais presente no imaginário geral.

Sendo os trabalhos de investigação positivamente relacionáveis com as notícias produzidas, não é de surpreender que nos concelhos onde estes são não-existentes/pouco expressivos exista, de facto, menos matéria noticiada.

Verifica-se também a grande concentração de notícias na região litoral. Tal pode dever-se a, pelo menos, três ordens de razão: i) a presença humana mais intensa, actualmente, no litoral do que noutras áreas. ii) Às dificuldades acrescidas inerentes à logística na prospecção e escavação, tanto pelo acidentado terreno como pelas vias de comunicação mais parcas em uma das zonas mais isoladas de todo o Algarve (i.e. Serra), como o elegantemente exposto por Victor Gonçalves (1989, pp. 87-8 e 9o) demonstra. E, por fim, iii) sendo o litoral a região mais rica das três, e a que mais pressão turística tem, é clarividente que seja esta a que tenha mais verba para o financiamento de escavações de investigação como as que mais interesse tenham na actividade arqueológica, tendo em vista a sua rentabilização económica enquanto atractivo turístico, ou seja, na sua potencial comodificação.

\subsection{Cronologia}

Regista-se um domínio absoluto dos períodos históricos face aos pré-históricos e proto-históricos (Tabela 7). As notícias relacionas com o mundo romano $(38,8 \%)$ são as dominantes, seguindo-se as do período medieval islâmico isoladamente $(17,9 \%)$ e em junção com o medieval cristão (13,4\%).

Entrevendo-se uma realidade mais diluída, a imprensa regional encontra em três grandes períodos com dimensões estatísticas análogas as suas linhas mestras: Calcolítico (17,5\%), Romano (17,5\%) e Medieval Islâmico $(16,3 \%)$ (Tabela 8$)$.

Se uma das principais funções do jornal é vender, como o é na imprensa nacional, a escolha da cronologia dos sítios noticiados não é, de longe, inocente. O mundo histórico, na qual a antiguidade clássica figura por excelência, seja pelo cânone de que serviu durante séculos ou, por sua vez, pelo impacto cultural que o mesmo teve até aos dias de hoje, configura-se como uma realidade muito melhor conhecida do público em geral do que a anterior à presença romana. Os próprios jornalistas, não tendo particular formação ou sensibilidade na área da pré-história, não conseguem nela reconhecer o seu potencial enquanto bem económico. Os jornais, através da pré-história, não conseguem estabelecer tão facilmente comunicação entre a redacção e o pú- 
blico, ou seja, não se arriba a um contexto de significado comum (Luhmann, 200o, p. 15).

Como já argumentado, os jornais, à semelhança dos museus, são activos construtores da realidade para quem os lê. A escolha do período romano, manifestamente presente em qualquer das imprensas, para além das razões já acima expostas, prende-se também com a construção de uma identidade nacional cuja fundação é a romano-cristã. Bastará relembrar que a ideia de associação entre a nação portuguesa (na sua acepção enquanto povo) à Lusitânia não é, de longe, uma ideia recente ou em desuso em contexto popular.

Por outro lado, e isto é inescapável, existe um maior número de trabalhos de investigação que versam quer sobre o mundo romano (e.g. Monte Molião) quer sobre as realidades islâmicas (e.g. Cacela Velha e Silves), o que condiciona, à partida, as notícias que daqui brotarem.

Explica-se uma maior presença da pré-história na imprensa regional devido ao já argumentado no subcapítulo anterior: o menor potencial de comodificação de contextos pré-históricas, como Alcalar, reflectindo assim o peso distinto que este tem na imprensa nacional e nos seus congéneres regionais.

Com o advento das teorias pós-coloniais (Said, 2003 [1978]), a ideia do Oriente enquanto entidade "that is based on the Orient's special place in European Western experience" (Said, 2003, p. 1) foi tornada cognoscível. Ainda assim, e embora largos sejam os passos que já foram dados desde os finais da década de 70 , ainda primam em plataformas com uma tremenda exposição construções do mundo islâmico enquanto algo exótico e distante. O arquétipo islâmico vendido é metonímico de um Oriente orientalizado pelo Ocidente, que nada é mais, para o comum do europeu que o consume, do que "one of its deepest and most recurring images of the Othern (Said, 2003, p. 1).

Procurando ilustrar o exposto, atente-se à pequena peça jornalística, da autoria de Idálio Revez e Joana Bourgard (2014), intitulada de «Descoberto complexo balnear islâmico único em Portugal». Nela, para além da total comodificação do património arqueológico ao serviço do turismo estival, é possível auditar, tanto no início como no final, acompanhado de um cenário que foca e particulariza vários elementos de um complexo balnear no extremo ocidente da Europa, a «Güldür Gül», uma canção sufi, otomana e cantada em turco!
Posto isto, é também possível defender um certo orientalismo nos processos de comodificação do património islâmico em Portugal.

\subsection{Natureza dos trabalhos}

Os trabalhos de Tipo A abrangem mais do que a maioria das notícias (55,2\%\%). Salvante os de Tipo B, que estão em segundo lugar com $29,3 \%$, os demais são de pouca significância estatística (Tabela 9). Não obstante o elevado número de intervenções de Tipo C, e algumas de Tipo D, estas apresentam-se sub-representadas na imprensa nacional.

À semelhança do evidenciado nos jornais nacionais, destaca-se em primeiro plano os trabalhos de investigação, com 49,4\%, seguido dos atinentes à valorização e musealização, com 30,6\% (Tabela 10). É de notar a acrescida importância dos trabalhos Tipo C neste tipo de imprensa.

Resultando claro o peso dos trabalhos de investigação no que acaba por ser a sua expressão editorial tanto nas plagas algarvias como em âmbito nacional, queda-se como (aparentemente) estranha a ausência dos trabalhos de Tipo C, de longe os mais frequentes dos trabalhos de campo. Tal poderá ser explicado pelo carácter pouco visível, muito fragmentado e de difícil reconhecimento das realidades arqueológicas produzidas pela arqueologia preventiva.

Também nos trabalhos de investigação, que são quase sempre financiados por entidades locais e públicas (i.e. câmaras municipais), são os próprios organismos camarários os que muitas das vezes entram em contacto com as redacções de jornais, trazendo jornalistas aos sítios e, assim, aumentando a visibilidade dos projectos a serem empreendidos.

A maior assiduidade das notícias analisadas nos media regionais que têm como enquadramento legal os trabalhos de Tipo C queda-se justificada, uma vez mais, numa maior importância dada à dimensão de serviço público e dever informativo às populações locais.

As notícias relativas à musealização de bens arqueológicos exumados de contextos algarvios na imprensa nacional estão quase exclusivamente relacionadas com o Museu Nacional de Arqueologia, em Lisboa. Nos jornais regionais, onde a atenção é, naturalmente, voltada às realidades algarvias, tal não se sucede. Contudo, há que questionar se a sub-representação presente na imprensa nacional não se poderá relacionar com uma visão centralizadora - afim da evidenciada há longos anos na administração pública na- 
cional. Da mesma forma como os principais órgãos de gestão têm em Lisboa a sua residência, também a grande maioria das sedes das redacções se situam na capital, criando uma visão geograficamente unívoca.

\section{REFLEXÕES FINAIS, OU DA COMODIFI- CAÇÃO DE UM ESTEREÓTIPO}

\begin{abstract}
"AL JIZAH, EGYPT - A team of British and Egyptian archaeologists made a stunning discovery Monday, unearthing several intact specimens of "skeleton people" - skinless, organless humans who populated the Nile delta region an estimated 6,ooo years ago.» "Archaeological Dig uncovers Ancient Race of Skeleton People» - Notícia do "The Onion» de 8/12/99, com o humor que lhe é próprio.
\end{abstract}

A presença da arqueologia algarvia nos jornais possui características distintas consoante a imprensa em questão, reflectindo acima de tudo a natureza dissimilante entre ambas as redacções. A nacional precipita-se naturalmente para uma maior comodificação da arqueologia, por ter um interesse acrescido na obtenção de lucro através da extracção de mais-valia na produção de notícias e peças jornalísticas (e.g. vide Ribeiro, 2001, p. 81). A regional, por sua vez, por ter uma relação mais próxima e forte às comunidades locais e por se dedicar a uma região em concreto, juntamente com formações de base distintas, dá espaço a notícias não tão facilmente tornadas simples produto económico. O tratamento muito diferenciado dado à pré-história e uma maior abrangência regional na imprensa regional são disso justo exemplo (Tabela 5, 6, 7 e 8).

A sobre-representação do litoral algarvio face às demais regiões queda-se justificada pela sua maior capacidade económica, podendo financiar trabalhos de campo de investigação nos seus territórios - de longe os mais patentes nos jornais (tabela 9 e 10).

Não sendo o jornalismo uma ilha isolada do mundo que o rodeia, nela ainda se reflecte todo um conjunto de visões sobre o passado e o Outro que em muito trespassam o âmbito dos jornais, como um certo orientalismo atesta. Infelizmente, os jornais não mobilizam a arqueologia e os seus contributos para discutir de forma crítica temáticas fracturantes, como, por exemplo, o que fazer com restos humanos de contextos da escravatura africana.

Uma vez feita a reflexão sobre as razões que motivam a escolha de temas arqueológicos para entrin- cheirarem nos jornais e como ela é feita, importa perceber qual é a imagem que é transmitida para o grande público sobre a arqueologia. Importa compreender quais os trâmites em que a arqueologia passa para ser tornada em peça jornalística rentável. Importa, por isso, perceber a Arqueologia enquanto Marca (Holtorf, 2016), com as subsequentes implicações na percepção do(s) passado(s) e da própria actividade arqueológica.

Perpassam essencialmente dois grandes estereótipos da arqueologia e da sua prática: o tema $\mathrm{R}$ (o mais frequente), definido pela arqueologia enquanto fonte de revelações sensacionais (Holtorf, 2016, p. 84); e, este já em menor grau, o tema $\mathrm{D}$, onde o arqueólogo é apresentado como se tratasse de um detective em funções (Holtorf, 2016, pp. 75-6).

Ambos os estereótipos não são, aliás, mutualmente exclusivos, muito antes pelo contrário (Holtorf, 2016, p. 85).

Também se verifica a existência de notícias onde é outorgado aos achados o papel unilateral da produção de conhecimento. A arqueologia queda-se destarte na simples audição de um artefacto "falante". Estes são assim a grande fonte para os tempos pretéritos. Neste ensejo o arqueólogo torna-se somente mero trabalhador mecânico e perfeitamente alienado do seu trabalho para extrair da terra a História, não tendo particular questionário científico a responder nem participando no processo interpretativo - que espaço tem sequer o arqueólogo na interpretação de uma materialidade tão (aparentemente) clarividente? É neste pêndulo entre o essencialismo e o antiquarismo em que os artefactos, enquanto testemunho metonímico de um Passado único, são $O$ Passado. Esta philos artefactualista perpetua uma visão acrítica do passado e poda o que podia ser uma frondosa árvore de complexidade, reduzindo os tempos pretéritos a simples engenho de consumo fácil a um vasto público - qual fast-food cultural. A História arqueológica passa a ser cognoscível através do vaso per se, votando ao oblívio tanto a sociedade que o produziu como as contradições internas desta. Os jornais comungam assim de uma visão de uma arqueologia enquadrada numa narrativa aventuresca - quiçá militar - onde os nossos Indiana Jones, após intensos prélios, podem mostrar ao mundo os espólios das suas conquistas: os materiais arqueológicos (Holtorf, 2016, p. 65).

A arqueologia aparece também intimamente associada ao enigma, servindo desta forma como mais 
um mecanismo de comodificação. Conforme já observado por Holtfort (2016, p. 9o), a arqueologia pode em parte ser comparada a filmes de terror ou aos $X$-Files, não pela melosa voz da Scully ou o cinismo do Mulder, mas sim porque ambos lidam com o desconhecido e o mistério, assim se aparentando ao grande público.

Conquanto seja evidente a comodificação que a arqueologia é alvo, esta não se opera em todas as suas dimensões. Tomando por base a partição de Moshenska (2009, pp. 46-7) e adaptando-a à realidade em discussão, a arqueologia é comodificada principalmente em duas dimensões nos jornais: através da imagética que produz (tipo 5) e do material arqueológico (tipo 1). A natureza interligada de ambos reforça o foco fetichista do artefacto dado pelos jornais. Mais do que propriamente um apanágio ou uma inovação da imprensa portuguesa, há que levantar a possibilidade desta forma de apresentar e representar o passado corresponder à sedimentação discursiva perpetuada por revistas internacionais de impacto global, como a National Geographic. De facto, são várias as parecenças verificadas na análise do presente objecto de estudo e as descritas por Joan Gero e Dolores Root (1990) para esta revista, como a visão de um passado resumido ao artefacto (p. 28 e 34) e o leitmotiv do explorador/aventura (p. 27). Não se verificou, contudo, a importante crítica androcêntrica que as autoras fazem à NatGeo em qualquer das imprensas. Este facto pode dever-se, em parte, à relativa paridade de género em quem assina as notícias relacionadas com a arqueologia.

No que é atinente à relação entre a arqueologia e a divulgação jornalística: mesmo que o arqueólogo seja um narrador por excelência, havendo no contacto com o público um lado demarcadamente performativo (Fagan, 2002, p. 254), este é proscrito a mero apontamento, a um detalhe não relevante na notícia. A sua palavra é somente utilizada como o enunciar das "pistas» sobre as realidades em apreço - qual detective em trabalho. Se Alfred Kidder (1949) tivesse de rescrever os dois tipos de arqueólogos que postulou no imaginário popular, sendo estes o "hairy-chested" e o "hairy-chinned», e à luz do já exposto, teria de incluir um terceiro tipo: o mudo. Todavia, a referenciação da palavra do arqueólogo nas notícias - citando-o directamente - não pode ser descartada como também sendo um mecanismo de salvaguarda das redacções que assim evitam a construção de uma imagem pública de jornal=verdade, com a sua consequente validade apriorística a evitar (Luhmann, 2000, p. 5).

A forma como a arqueologia e a sua materialidade é encarada na imprensa, muito mais do que corresponder a um intento de transmitir informação, encontra expressão numa condição de entretenimento (se entendida como uma quasi-heterotopia - vide Luhmann, 200o, pp. 51-52) - um entretenimento sofisticado de consumo rápido. Deveras, a comodificação da cultura ao serviço dos interesses económicos resulta tendencialmente na castração do pensamento reflexivo, onde "Thought becomes short-winded, confines itself to apprehending isolated facts. Intellectual connections are rejected as an inconvenient and useless exertion.» (Horkheimer e Adorno, 2002, p. 163; sem negrito no original).

\subsection{E concluindo um trabalho em eterno devir...} Por fim, considera-se que a inexistência de uma sólida organização interna dentro da comunidade arqueológica, dotando-nos de força e coesão, não permite à classe ter a expressividade e o peso desejáveis na sociedade civil. Enquanto tal não for ultrapassado, dificilmente poderá sistematicamente o arqueólogo ter uma palavra a dizer sobre a (re)construção do(s) passado(s) nos media.

A prática de redacção em jornais sobre matéria arqueológica em muito pode ser majorada qualitativamente se for o próprio arqueólogo a escrever. Mais do que um despautério utópico, é de salientar o conjunto de notícias no Sul Informação, assinadas por Cristina Tété Garcia e Maria João Valente, intituladas «Crónicas de uma escavação arqueológican. Aqui, para além haver um claro cunho pedagógico bem conseguido (i.e. sem entrar em paternalismos desnecessários), são explicados não só os processos de escavação arqueológica como o que foi intervencionado. E é apresentada uma visão humana sobre o extraído dos arquivos pétreos da História, ficando patente que quem habitou o espaço foram pessoas e não meros artefactos (aparentemente) desirmanados.

Só a sistemática integração de arqueólogos nas trincheiras jornalísticas pode alterar decisivamente o paradigma vigente. Tal pode ter consequências muito positivas não só para a percepção do público do arqueólogo e do seu métier como tornar a exposição de tempos pretéritos numa salubre prática reflexiva, anulando os sensacionalismos (que é, aliás, parte do ponto 2 do código deontológico dos jornalistas) e desvelando o que de tão humano há nas copiosas 
materialidades que escavamos. É esse mesmo lado humano que falta. E se a arqueologia que se deseja em plena centúria de XXI é uma onde exista intensa relação com o público, retribuindo às comunidades locais e nacionais o fruto do labor arqueológico, urge a reflexão sobre as formas como a arqueologia é consumida e transmitida (Moshenska, 2009, p. 47). E rapidamente.

Que a todos sirva de estímulo para as mais salutares reflexões futuras.

Vale

\author{
Primeira versão de Outono de 2019, \\ revisto e ampliado na Primavera e terminado \\ nos primeiros dias estivais de 2020 , \\ Península de Lisboa
}

\section{AGRADECIMENTOS}

Há que agradecer à Prof. Miguel Calado e ao Philipp Teuchmann pela revisão do texto, pelos preciosos comentários e pelas salubres discussões (na acepção anglo-saxónica do termo) queacrescentaram insofismávelvalorao presente artigo. Agradeço também à Prof. a Ana Margarida Arruda pelos perspicazes comentários a uma primeira versão do texto, ainda em contexto académico livre de pandemias, assim como o desafio de avançar com a publicação. O produto final é, evidentemente, da exclusiva responsabilidade dos autores.

\section{BIBLIOGRAFIA}

CORREIA, João (1998) - Jornalismo regional e cidadania. Biblioteca On-line de Ciências da Comunicação. pp. 1-6.

ERNST, Wolfgang (2013) - Digital memory and the archive. 1st. ed. Minneapolis: University of Minnesota Press.

Fagan, Brian (2002) - Epilogue. In LITTLE, Barbara, eds. Public Benefits of Archaeology. Gainesville: University Press of Florida. pp. 253-6o.

GERO, Joan; ROOT, Dolores (1990) - Public Presentations and Private Concerns: Archaeology in the Pages of National Geographic. In GATHERCOLE, Peter; LOWENTHAL, David, eds. - The Politics of the Past. London: Unwin Himan. pp. 532-548.

GHIZZONI, Manuela (2013) - Jornalismo Regional como Mediador Social: Uma Análise de Conteúdo. Revista Vernáculo. 32, pp. 136-166.

GONÇALVES, Victor Santos (1989) - Megalitismo e metalurgia no Alto Algarve Oriental: uma aproximação integrada. Lisboa: Instituto Nacional de Investigação Científica.
HOLTORF, Cornelius (2016) - Archaeology Is a Brand! The meaning of archeology in contemporary popular culture. London and New York: Routledge.

HORKHEIMER, Max; ADORNO, Theodor (2002) - Dialectic of Enlightenment: Philosophical Fragments. Standford: Stanford University Press.

LUHMANN, Niklas (200o) - The Reality of the Mass Media. Standford: Stanford University Press.

LYOTARD, Jean François (1992) - La phenomenologie. $11^{\text {th }}$. ed. Paris: Presses Universitaires de France.

MORO ABADÍA, Oscar (2009) - The History of Archaeology as Seen Through the Externalism-Internalism Debate: Historical Development and Current Challenges. Bulletin of the History of Archaeology. 19. 2, pp.13-26.

MOSHENSKA, Gabriel (2009) - What is Public Archaeology? Present Pasts. 1, pp. 46-48.

PASCOAL, Isabel (2008) - Os jornalistas da imprensa regional e os condicionalismos ao exercício da profissão. In III Congresso Português de Sociologia: Práticas e Processos da Mudança Social. pp. 1-13.

PEREIRA, Fábio (2004) - Da responsabilidade social ao jornalismo de mercado: o jornalismo como profissão. Biblioteca On-line de Ciências da Comunicação. pp. 1-15.

REVEZ, Idálio; BOURDARD, Joana (2014) - Descoberto complexo balnear islâmico único em Portugal. Público. https://www.publico.pt/2014/o1/23/video/complexo-balnear-islamico-unico-em-portugal-2014012O-184030

RIBEIRO, Jorge (2001) - Sempre Alerta: condições e contradições do trabalho jornalístico. São Paulo: Olho d'Água.

SAID, Edward (2003) - Orientalism: Western Conceptions of the Orient. $5^{\text {th }}$. ed. London: Penguin Books.

SHANKS, Michael; TILLEY, Christopher (1988) - Social Theory and Archaeology. Albuquerque: University of New Mexico Press. 
Modalidade - Imp. Nacional

\begin{tabular}{ll|l|l|l|l} 
& & Frequência & Percentagem & Percentagem válida & $\begin{array}{l}\text { Percentagem } \\
\text { acumulativa }\end{array}$ \\
\hline \multirow{2}{*}{ Válido } & Directa & 75 & 93,8 & 93,8 & 93,8 \\
\cline { 2 - 6 } & Indirecta & 5 & 6,3 & 6,3 & 100,0 \\
\cline { 2 - 6 } & Total & 80 & 100,0 & 100,0 & \\
\hline
\end{tabular}

Tabela 1 - Tabela descritiva das modalidades das notícias publicadas na imprensa nacional (valores arredondados à décima).

\begin{tabular}{|c|c|c|c|c|c|}
\hline & & Frequência & Percentagem & $\begin{array}{l}\text { Percentagem } \\
\text { válida }\end{array}$ & $\begin{array}{l}\text { Percentagem } \\
\text { acumulativa }\end{array}$ \\
\hline \multirow[t]{3}{*}{ Válido } & Directa & 181 & 68,8 & 68,8 & 68,8 \\
\hline & Indirecta & 82 & 31,2 & 31,2 & 100,0 \\
\hline & Total & 263 & 100,0 & 100,0 & \\
\hline
\end{tabular}

Tabela 2 - Tabela descritiva das modalidades das notícias publicadas na imprensa nacional (valores arredondados à décima).

\section{Mês - Imp. Nacional}

\begin{tabular}{|c|c|c|c|c|c|}
\hline & & Frequência & Percentagem & $\begin{array}{l}\text { Percentagem } \\
\text { válida }\end{array}$ & $\begin{array}{l}\text { Percentagem } \\
\text { acumulativa }\end{array}$ \\
\hline \multirow[t]{12}{*}{ Válido } & Janeiro & 6 & 7,5 & 7,5 & 7,5 \\
\hline & Fevereiro & 4 & 5,0 & 5,0 & 12,5 \\
\hline & Março & 1 & 1,3 & 1,3 & 13,8 \\
\hline & Abril & 7 & 8,8 & 8,8 & 22,6 \\
\hline & Maio & 10 & 12,5 & 12,5 & 35,1 \\
\hline & Junho & 12 & 15,0 & 15,0 & 50,1 \\
\hline & Julho & 16 & 20,0 & 20,0 & 70,1 \\
\hline & Agosto & 10 & 12,5 & 12,5 & 82,6 \\
\hline & Setembro & 11 & 13,8 & 13,8 & 96,4 \\
\hline & Outubro & 1 & 1,3 & 1,3 & 97,7 \\
\hline & Dezembro & 2 & 2,5 & 2,5 & 100 \\
\hline & Total & 80 & 100,0 & 100,0 & \\
\hline
\end{tabular}

Tabela 3 - Tabela descritiva da data de publicação das notícias da imprensa nacional distribuída por meses (valores arredondados à décima). 


\section{Mês - Imp. Regional}

\begin{tabular}{|c|c|c|c|c|c|}
\hline & & Frequência & Percentagem & $\begin{array}{l}\text { Percentagem } \\
\text { válida }\end{array}$ & $\begin{array}{l}\text { Percentagem } \\
\text { acumulativa }\end{array}$ \\
\hline \multirow[t]{13}{*}{ Válido } & Janeiro & 10 & 3,8 & 3,8 & 3,8 \\
\hline & Fevereiro & 19 & 7,2 & 7,2 & 11,0 \\
\hline & Março & 26 & 9,9 & 9,9 & 20,9 \\
\hline & Abril & 29 & 11,0 & 11,0 & 31,9 \\
\hline & Maio & 27 & 10,3 & 10,3 & 42,2 \\
\hline & Junho & 22 & 8,4 & 8,4 & 50,6 \\
\hline & Julho & 34 & 12,9 & 12,9 & 63,5 \\
\hline & Agosto & 29 & 11,0 & 11,0 & 74,5 \\
\hline & Setembro & 26 & 9,9 & 9,9 & 84,4 \\
\hline & Outubro & 18 & 6,8 & 6,8 & 91,2 \\
\hline & Novembro & 19 & 7,2 & 7,2 & 98,4 \\
\hline & Dezembro & 4 & 1,5 & 1,5 & 100 \\
\hline & Total & 263 & 100,0 & 100,0 & \\
\hline
\end{tabular}

Tabela 4 - Tabela descritiva da data de publicação das notícias da imprensa regional distribuída por meses (valores arredondados à décima).

\section{Concelho-Imp. Nacional}

\begin{tabular}{|c|c|c|c|c|c|}
\hline & & Frequência & Percentagem & $\begin{array}{l}\text { Percentagem } \\
\text { válida }\end{array}$ & $\begin{array}{l}\text { Percentagem } \\
\text { acumulativa }\end{array}$ \\
\hline \multirow[t]{18}{*}{ Válido } & & 6 & 7,5 & 7,5 & 7,5 \\
\hline & Albufeira & 2 & 2,5 & 2,5 & 10,0 \\
\hline & Alcoutim & 1 & 1,3 & 1,3 & 11,3 \\
\hline & Aljezur & 3 & 3,8 & 3,8 & 15,0 \\
\hline & Castro Marim & 1 & 1,3 & 1,3 & 16,3 \\
\hline & Faro & 4 & 5,0 & 5,0 & 21,3 \\
\hline & Lagoa & 2 & 2,5 & 2,5 & 23,8 \\
\hline & Lagoa (e Viana do Castelo) & 1 & 1,3 & 1,3 & 25,0 \\
\hline & Lagos & 5 & 6,3 & 6,3 & 31,3 \\
\hline & Loulé & 16 & 20,0 & 20,0 & 51,2 \\
\hline & Monchique & 1 & 1,3 & 1,3 & 52,5 \\
\hline & Portimão & 1 & 1,3 & 1,3 & 53,8 \\
\hline & Sagres & 2 & 2,5 & 2,5 & 56,3 \\
\hline & Silves & 2 & 2,5 & 2,5 & 58,8 \\
\hline & Tavira & 13 & 16,3 & 16,3 & 75,0 \\
\hline & Vila do Bispo & 8 & 10,0 & 10,0 & 85,0 \\
\hline & Vila Real de Santo António & 12 & 15,0 & 15,0 & 100,0 \\
\hline & Total & 80 & 100,0 & 100,0 & \\
\hline
\end{tabular}

Tabela 5 - Tabela descritiva da geografia das notícias da imprensa nacional distribuída por concelhos (valores arredondados à décima). 


\begin{tabular}{|c|c|c|c|c|c|}
\hline & & Frequência & Percentagem & $\begin{array}{l}\text { Percentagem } \\
\text { válida }\end{array}$ & $\begin{array}{l}\text { Percentagem } \\
\text { acumulativa }\end{array}$ \\
\hline \multirow[t]{24}{*}{ Válido } & . & 1 &, 4 & 4 & ,4 \\
\hline & Albufeira & 7 & 2,7 & 2,7 & 3,0 \\
\hline & Alcoutim & 2 & 8 & 8 & 3,8 \\
\hline & Aljezur & 4 & 1,5 & 1,5 & 5,3 \\
\hline & Castro Marim & 1 & 4 & 4 & 5,7 \\
\hline & Faro & 27 & 10,3 & 10,3 & 16,0 \\
\hline & Lagoa & 2 & 8 & 8 & 16,7 \\
\hline & Lagoa e São Brás de Alportel & 1 & 4 & 4 & 17,1 \\
\hline & Lagos & 14 & 5,3 & 5,3 & 22,4 \\
\hline & Lagos e Portimão & 1 & ,4 &, 4 & 22,8 \\
\hline & Loulé & 52 & 19,8 & 19,8 & 42,6 \\
\hline & Loulé (e Almodôvar) & 1 &, 4 &, 4 & 43,0 \\
\hline & Monchique & 4 & 1,5 & 1,5 & 44,5 \\
\hline & Olhão & 1 &, 4 &, 4 & 44,9 \\
\hline & Portimão & 40 & 15,2 & 15,2 & 60,1 \\
\hline & Portimão e Loulé & 1 &, 4 &, 4 & 60,5 \\
\hline & $\begin{array}{l}\text { Portimão, Lagoa, Silves } \\
\text { e Monchique }\end{array}$ & 2 & 8 & 8 & 61,2 \\
\hline & São Brás de Alportel & 4 & 1,5 & 1,5 & 62,7 \\
\hline & Silves & 35 & 13,3 & 13,3 & 76,0 \\
\hline & Tavira & 20 & 7,6 & 7,6 & 83,7 \\
\hline & Vários & 4 & 1,5 & 1,5 & 85,2 \\
\hline & Vila do Bispo & 30 & 11,4 & 11,4 & 96,6 \\
\hline & Vila Real de Santo António & 9 & 3,4 & 3,4 & 100,0 \\
\hline & Total & 263 & 100,0 & 100,0 & \\
\hline
\end{tabular}

Tabela 6 - Tabela descritiva da geografia das notícias da imprensa regional distribuída por concelhos (valores arredondados à décima). 


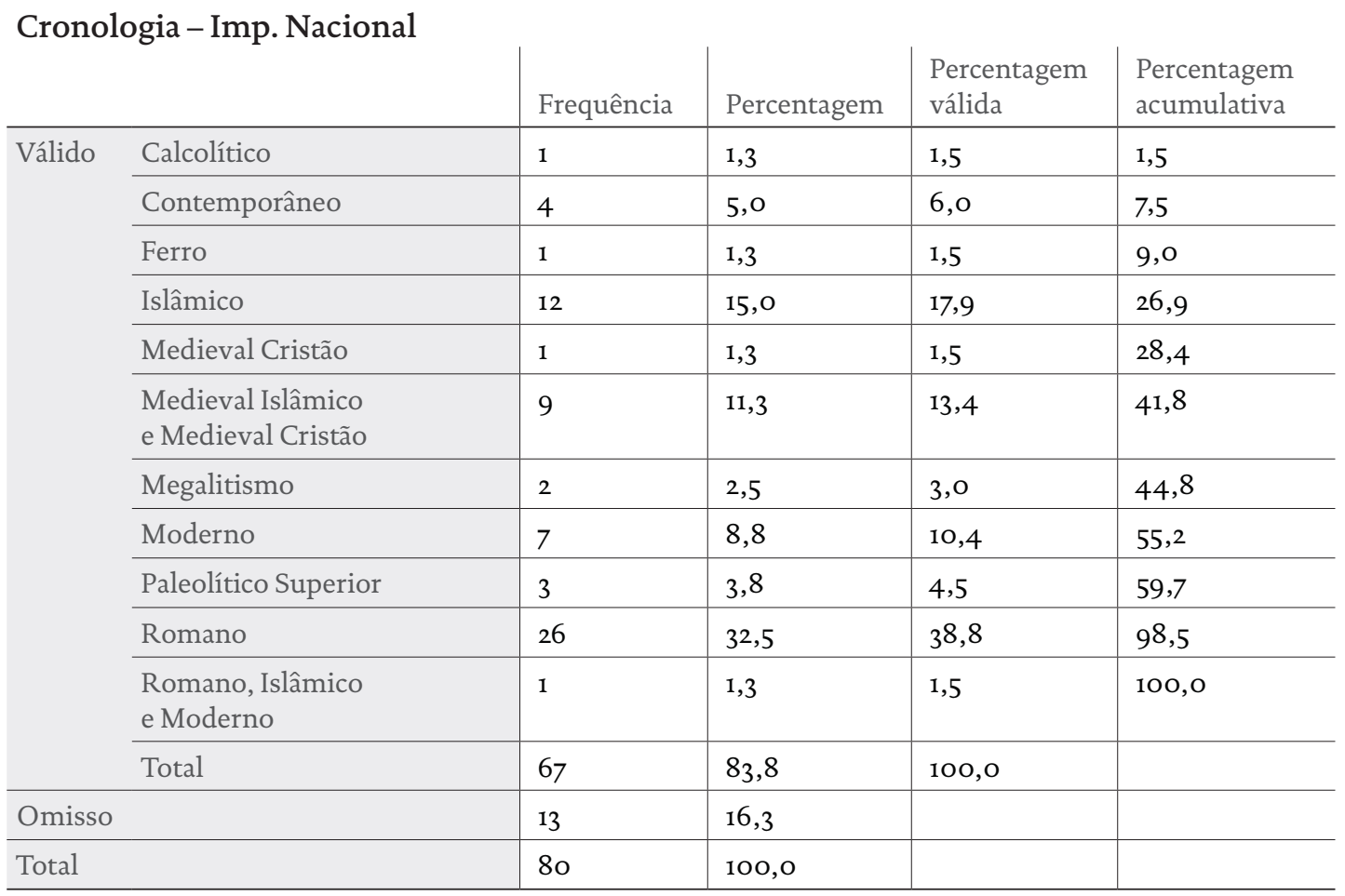

Tabela 7-Tabela descritiva das cronologias mencionadas das notícias publicadas na imprensa nacional (valores arredondados à décima).

\begin{tabular}{|c|c|c|c|c|c|}
\hline \multicolumn{6}{|c|}{ Cronologia - Imp. Regional } \\
\hline & & Frequência & Percentagem & válida & acumulativa \\
\hline \multirow[t]{16}{*}{ Válido } & Calcolítico & 14 & 5,3 & 17,5 & 17,5 \\
\hline & $\begin{array}{l}\text { Calcolítico, Romano, } \\
\text { Medieval }\end{array}$ & 1 & 4 & 1,3 & 18,8 \\
\hline & Contemporâneo & 2 & 8 & 2,5 & 21,3 \\
\hline & Idade do Bronze, Islâmico & 2 & 8 & 2,5 & 23,8 \\
\hline & Idade do Ferro, Romano & 7 & 2,7 & 8,8 & 32,5 \\
\hline & Islâmico & 13 & 4,9 & 16,3 & 48,8 \\
\hline & Islâmico e Medieval Cristão & 8 & 3,0 & 10,0 & 58,8 \\
\hline & Moderno & 5 & 1,9 & 6,3 & 65,0 \\
\hline & Moderno e Contemporâneo & 1 & 4 & 1,3 & 66,3 \\
\hline & Paleolítico & 7 & 2,7 & 8,8 & 75,0 \\
\hline & Romano & 14 & 5,3 & 17,5 & 92,5 \\
\hline & Romano até Contemporâneo & 2 & 8 & 2,5 & 95,0 \\
\hline & Romano, Moderno & 2 & 8 & 2,5 & 97,5 \\
\hline & $\begin{array}{l}\text { Romano, Moderno, } \\
\text { Contemporâneo }\end{array}$ & 1 & 4 & 1,3 & 98,8 \\
\hline & Tardo-Medieval & 1 & 4 & 1,3 & 100,0 \\
\hline & Total & 80 & 30,4 & 100,0 & \\
\hline Omisso & & 183 & 69,6 & & \\
\hline Total & & 263 & 100,0 & & \\
\hline
\end{tabular}

Tabela 8 - Tabela descritiva das cronologias mencionadas das notícias publicadas na imprensa regional (valores arredondados à décima). 
Natureza dos trabalhos - Imp. Nacional

\begin{tabular}{ll|l|l|l|l} 
& & & & & \\
& & Frequência & Percentagem & $\begin{array}{l}\text { Percentagem } \\
\text { válida }\end{array}$ & $\begin{array}{l}\text { Percentagem } \\
\text { acumulativa }\end{array}$ \\
\hline Válido & Tipo A & 32 & 40,0 & 55,2 & 55,2 \\
\cline { 2 - 6 } & Tipo B & 17 & 21,3 & 29,3 & 84,5 \\
\cline { 2 - 6 } & Tipo C & 8 & 10,0 & 13,8 & 98,3 \\
\cline { 2 - 6 } & Tipo D & 1 & 1,3 & 1,7 & 100,0 \\
\hline & Total & 58 & 72,5 & 100,0 & \\
\hline Omisso & 22 & 27,5 & & \\
\hline Total & 80 & 100,0 & &
\end{tabular}

Tabela 9- Tabela descritiva da natureza legal dos trabalhos arqueológicos mencionados nas notícias publicadas na imprensa nacional (valores arredondados à décima).

\begin{tabular}{|c|c|c|c|c|c|}
\hline & & Frequência & Percentagem & $\begin{array}{l}\text { Percentagem } \\
\text { válida }\end{array}$ & $\begin{array}{l}\text { Percentagem } \\
\text { acumulativa }\end{array}$ \\
\hline \multirow[t]{4}{*}{ Válido } & Tipo A & 42 & 16,0 & 49,4 & 49,4 \\
\hline & Tipo B & 26 & 9,9 & 30,6 & 80,0 \\
\hline & Tipo C & 17 & 6,5 & 20,0 & 100,0 \\
\hline & Total & 85 & 32,3 & 100,0 & \\
\hline Omisso & & 178 & 67,7 & & \\
\hline Total & & 263 & 100,0 & & \\
\hline
\end{tabular}

Tabela 10 - Tabela descritiva da natureza legal dos trabalhos arqueológicos mencionados nas notícias publicadas na imprensa regional (valores arredondados à décima). 


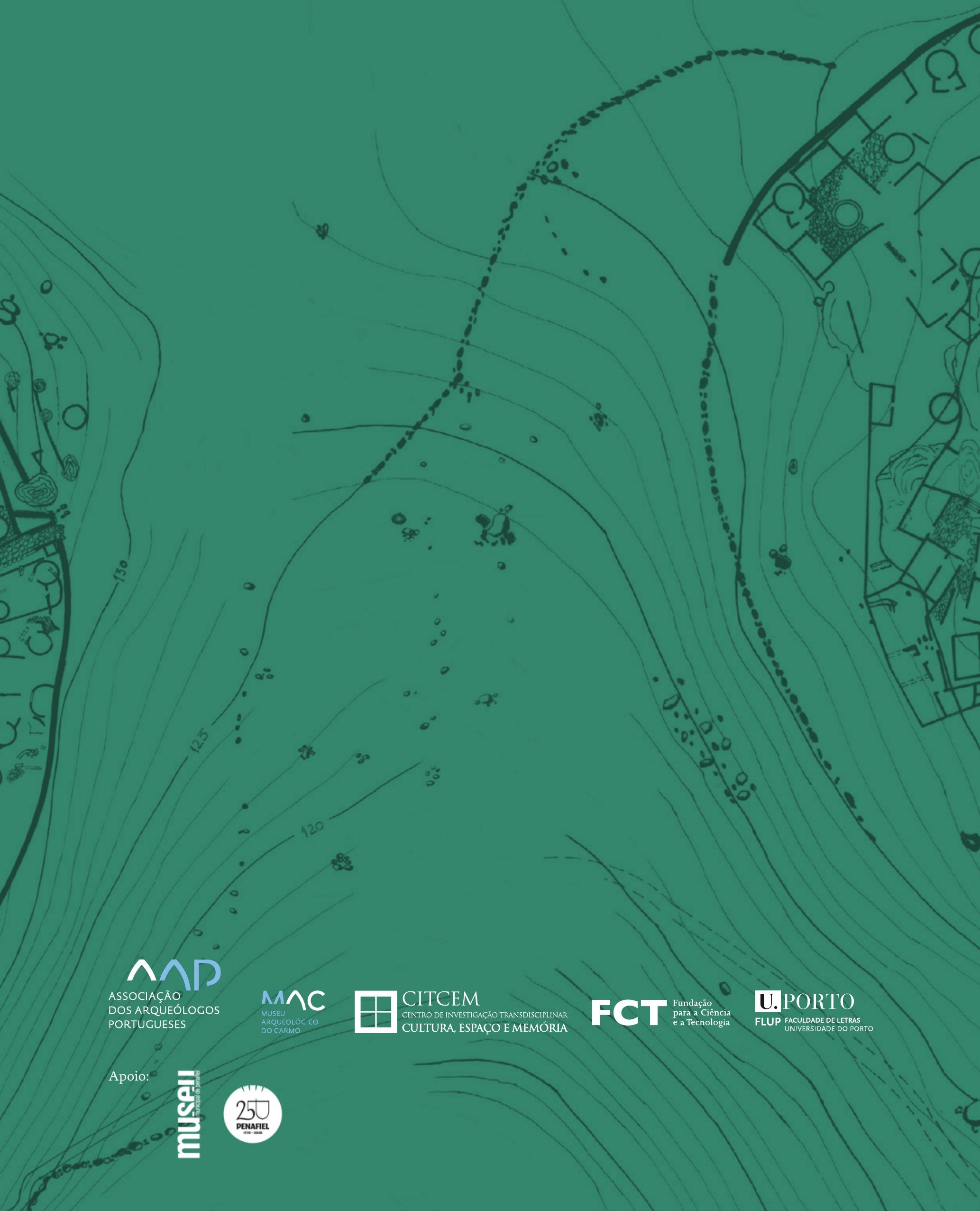

